\title{
Lasten ja nuorten verkkokiusaamisen tutkimushaasteita
}

\author{
Heidi Nieminen \& Maili Pörhölä
}

\section{Tiivistelmä}

Verkkokiusaaminen (cyberbullying) on suhteellisen uusi käsite, jolla tarkoitetaan viestintäteknologian kuten sähköpostin, puhelimen tai sosiaalisen median välityksellä tapahtuvaa loukkaamista ja vahingoittamista. Vaikka ilmiö on saanut mediassa paljon julkisuutta, on verkkokiusaamisen tutkimus käynnistynyt vasta 2000-luvun puolivälissä. Tutkijat ovat olleet kiinnostuneita erityisesti lasten ja nuorten keskuudessa esiintyvästä verkkokiusaamisesta, josta onkin muutamassa vuodessa kasvanut yksi koulumaailman vakavimmista ongelmista.

Tässä kirjallisuuskatsauksessa ${ }^{1}$ kuvataan, miten verkkokiusaamista on määritelty ja millaisia erityispiirteitä siinä on tunnistettu. Lisäksi kootaan verkkokiusaamisen keskeisimpiä tutkimuskohteita ja pohditaan, millaisia haasteita verkkokiusaamisen tutkimiseen liittyy. Vaikka verkkokiusaamisen erityispiirteitä jo tunnetaankin, katsaus osoittaa ilmiön määrittelyn olevan vielä puutteellista. Tutkimuksen kohteita on toistaiseksi ollut niukasti ja tutkimusmenetelmät ovat olleet yksipuolisia.

Asiasanat: internet, kiusaaminen, lapset, nuoret, verkkokiusaaminen, viestintä, vuorovaikutussuhteet

\section{Johdanto}

Vaikka viestintäteknologialla on merkittävä rooli nykynuoren elämässä, sen käyttöä ja merkitystä nuorten sosiaalisissa suhteissa ymmärretään vielä valitettavan huonosti (Buckingham 2004, 79). Teknologian välityksellä tapahtuva kiusaaminen on ilmiö, joka on lisääntyvässä määrin herättänyt huolta niin kasvattajien kuin tutkijoidenkin keskuudessa. Sitä pidetään yhtenä koulumaailman vakavimmista ja nopeimmin kasvavista ongelmista (Campbell 2005; Li 2008).

Lasten ja nuorten keskuudessa esiintyvä verkkokiusaaminen on saanut paljon huomiota mediassa, mutta vain muutamat tutkijat ovat perehtyneet tähän

${ }^{1}$ Artikkeli perustuu Heidi Niemisen puheviestinnän pro gradu -tutkielmaan, jota ohjaa Maili Pörhölä. 
uuteen kiusaamisen muotoon (Kowalski \& Limber 2007). Ensimmäisen verkkokiusaamista käsittelevän empiirisen tutkimuksen julkaisivat Ybarra ja Mitchell vuonna 2004. Verkkokiusaaminen tapahtuu puhelimen, sähköpostin ja pikaviestinten välityksellä sekä levittämällä materiaalia internetissä. Teknologia mahdollistaa sen, että kiusaaminen voi tapahtua salassa, levitä nopeasti ja vaikuttaa pitkään (Agatston, Kowalski \& Limber 2007; Mason 2008; Slonje \& Smith 2008).

Verkkokiusaamisen seurauksia pidetään jopa vakavampina kuin perinteisen, kasvokkaistilanteissa tapahtuvan kiusaamisen. Monet perinteisen kiusaamisen uhrit kärsivät fyysisistä ja psykososiaalisista ongelmista kuten ahdistuneisuudesta, masentuneisuudesta, itsetuhoisista ajatuksista, syömishäiriöistä ja erilaisista sairauksista. Lisäksi kiusaamisen on todettu vaikuttavan itsetuntoon ja koulumenestykseen (ks. esim. Pörhölä 2009 kirjallisuuskatsausta). Verkkokiusaamisen uhrit kokevat tutkijoiden mukaan ahdistuneisuutta ja epävarmuutta vielä enemmän kuin perinteistä kiusaamista kokeneet, koska kiusaamista mahdollisesti seuraava yleisö on niin laaja ja tuntematon. Myös kiusaajan henkilöllisyys on uhrille usein epäselvä. (Beran \& Li 2005; Katzer, Fetchenhauer \& Belschak 2009; Mishna, Saini \& Solomon 2009; Ortega ym. 2009; Pure 2009.)

Verkkokiusaamisen tutkimista pidetään hankalana, koska se eroaa perinteisestä kiusaamisesta eivätkä tutkijat ole vielä päätyneet yhteiseen määritelmään ilmiöstä. Esimerkiksi kiusaamispaikan, tapahtuma-ajan ja toistuvuuden määrittäminen on verkkokiusaamisessa ongelmallista, koska teknologia on ajasta ja paikasta riippumatonta. Tässä kirjallisuuskatsauksessa tarkastellaan verkkokiusaamista käsitteleviä empiirisiä tutkimuksia ja kuvataan (1) miten verkkokiusaamista on määritelty ja millaisia erityispiirteitä sillä on nähty olevan, (2) mitkä ovat olleet verkkokiusaamisen keskeisimmät tutkimuskohteet ja (3) millaisia haasteita verkkokiusaamisen tutkimukseen liittyy.

Internetissä avoimesti olevien julkaisujen sekä Jyväskylän yliopiston kirjaston kautta saatavilla olevien tietokantojen avulla toteuttamamme kirjallisuuskartoitus osoitti, että vuosien 2004-2010 välillä kansainvälisissä tieteellisissä aikakauslehdissä on julkaistu kolmisenkymmentä verkkokiusaamista käsittelevää, empiiriseen alkuperäistutkimukseen pohjautuvaa tutkimusraporttia. Aihetta käsittelevien kirjallisuuskatsausten ja teoreettisten artikkeleiden määrä on huomattavasti suurempi. Analysoimme empiiriset tutkimusraportit poimimalla verkkokiusaamisesta käytetyt määritelmät ja ilmiön kuvailut sekä tiivistämällä keskeiset tutkimuskohteet ja käytetyt tutkimusmenetelmät. Nämä koottiin synteesiksi, jonka tulokset tiivistämme tässä artikkelissa. Kirjallisuuskatsaus alkaa verkkokiusaamisen määritelmien ja erityispiirteiden tarkastelulla. Sen jälkeen kokoamme verkkokiusaamisen keskeisimmät tutkimuskohteet. Puheviestinnän tutkimuksen kannalta erityisen mielenkiintoinen kohde on ollut läheisten vuorovaikutussuhteiden merkitys kiusaamisprosesseissa, mitä pohdimme erillisessä 
luvussa. Lopuksi tarkastelemme tutkimuksissa käytettyjä menetelmiä ja osoitamme niihin liittyviä haasteita.

\section{Verkkokiusaamisen määritteleminen}

Kiusaamisen tutkimus on alkujaan käynnistynyt psykologian tieteenalalla. Näistä lähtökohdista kiusaaminen onkin useimmiten määritelty aggressiiviseksi käyttäytymiseksi, ja perinteisen kiusaamisen ja verkkokiusaamisen on ajateltu pitkälti liittyvän toisiinsa (Li 2007a). Verkkokiusaamisen tutkijat ovat pääasiassa psykologian, kasvatustieteiden ja sosiologian tieteenaloilta sekä monitieteisistä tutkimusryhmistä, joissa nämä tieteenalat usein yhdistyvät. Verkkokiusaamista käsitteleviä empiirisiä tutkimuksia on niin ikään julkaistu voittopuolisesti psykologian aikakauslehdissä sekä monitieteisissä julkaisuissa.

Verkkokiusaamiseen viitataan yleensä englanninkielisellä termillä 'cyberbullying' (tai cyber bullying) ja toisinaan myös käsitteillä 'electronic/ internet/online harassment' tai 'online cruelty'. Termillä cyberbullying tarkoitetaan useimmiten kiusaamistilannetta, jossa kiusaava osapuoli tuntee uhrinsa ja valitsee tämän tietoisesti kiusaamisensa kohteeksi (Beran \& Li 2007; Mason 2008). Lisäksi on korostettu, että verkkokiusaamiselle on ominaista loukkaamisen ja vahingoittamisen toistuminen, vallan epätasapaino osapuolten välillä ja kiusaavan osapuolen mahdollisuus pysytellä anonyymina (Ševcíková \& Šmahel 2009).

Edellä mainituilla käsitteillä on kuitenkin nähty olevan myös sisällöllisiä eroja tutkijoista, tieteenalasta ja ajankohdasta riippuen. Varsinkin termejä online harassment ja internet harassment on käytetty myös laajemmassa merkityksessä kuvaamaan verkossa tapahtuvaa häirintää, joka voi kohdistua uhriin myös hänelle tuntemattoman henkilön taholta (esim. Hinduja \& Patchin 2007; Ybarra \& Mitchell 2004). Toisinaan cyberbullying onkin ymmärretty tämän laajemman käsitteen alakäsitteeksi ja yhdeksi verkossa tapahtuvan häirinnän muodoksi (esim. Hinduja \& Patchin 2007; Ševcíková \& Šmahel 2009; Ybarra \& Mitchell 2004).

Toisinaan käytettyjen käsitteiden merkitys on saattanut hämärtyä määrittelyn ja operationaalistuksen välisen ristiriidan vuoksi. Tutkimusraporttien teoriaosuudessa on saatettu selkeästi erotella kiusaaminen ja esimerkiksi salasanoja kalastelevat sähköpostiviestit eri ilmiöiksi, mutta menetelmäkuvauksesta ei selviä, ovatko tutkittavat olleet kyselyyn vastatessaan tietoisia siitä, mitä verkkokiusaamisella siinä tarkoitetaan.

Tutkijat ovat myös keskustelleet siitä, onko verkkokiusaaminen kokonaan oma ilmiönsä vai kiusaamisen uusi alalaji. Viimeaikaisten näkemysten mukaan verkkokiusaamista pidetään lähinnä yhtenä kiusaamisen muotona ennemminkin kuin erillisenä ilmiönä (esim. Beran \& Li 2007). Ortegan ja kumppaneiden (2009) mukaan verkkokiusaaminen rakentuu saman relationaalisen dynamiikan 
pohjalle kuin perinteinen kiusaaminenkin, ja samat roolit (uhrin ja kiusaajan) ovat tunnistettavissa kiusaamistilanteissa.

Verkkokiusaaminen on empiirisissä tutkimuksissa tyypillisesti määritelty käyttämällä perinteisen kiusaamisen määritelmää ja sijoittamalla se virtuaalimaailmaan (Juvonen \& Gross 2008; Schultze-Krumbholz \& Scheithauer 2009). Analysoimamme tutkimusraportit osoittivat, että enemmistö tutkijoista on perustanut määritelmänsä koulukiusaamista tutkineen Dan Olweuksen kiusaamisen määritelmälle.

"A person is bullied when he or she is exposed, repeatedly and over time, to negative actions on the part of one or more other persons, and he or she has difficulty defending himself or herself." (Olweus 1993, 9)

Olweus (1993) kuvaa kiusaamisen toistuvaksi aggressioksi ja systemaattiseksi vallankäytöksi yhden tai useamman oppilaan toimesta. Koska kiusaaminen perustuu vallan epätasapainoon, uhrin on vaikea puolustaa itseään. Koulukiusaamisen määrittelylle tyypillisellä tavalla kiusaamisen ajatellaan voivan olla fyysistä, verbaalista tai epäsuoraa vahingoittamista kuten kohteen sosiaalista eristämistä ja juorujen levittämistä hänestä.

Viestintäteknologian avulla voidaan välittää tekstiä, kuvaa ja ääntä. Fyysisen kiusaamisen muodot edellyttävät kosketusyhteyttä joko kiusaamisen uhriin tai ainakin hänen omaisuuteensa tai aikaansaannoksiinsa. Fyysinen vahingoittaminen ei siis olisi mahdollista virtuaaliympäristössä, mikä tulisikin ottaa huomioon verkkokiusaamista määriteltäessä.

Joissakin verkkokiusaamista käsittelevissä empiirisissä tutkimuksissa on viitattu Nancy Willardin määritelmään (esim. Beran \& Li 2007; Li 2008).

"Cyberbullying: Sending or posting harmful material or engaging in other forms of social aggression using the Internet or other digital technologies." (Willard 2007, 1)

Willardin (2007) mukaan verkkokiusaaminen on loukkaavan tekstin tai kuvan lähettämistä tai julkaisemista internetiä tai muita digitaalisia viestintävälineitä käyttäen. Tässä määritelmässä ei puolestaan huomioida lainkaan ääntä, joten esimerkiksi loukkaavat puhelut ja internetiin viedyt äänitallenteet eivät sisältyisi määritelmään.

Muutamassa tutkimuksessa on viitattu kiusaamista käsittelevän www.bullying.org -sivuston kehittäjän Bill Belseyn määritelmään (Cassidy, Jackson \& Brown 2009; Li 2007). Sen mukaan verkkokiusaaminen on yksilön tai ryhmän tahallista, vihamielistä ja toistuvaa käyttäytymistä, jonka tavoitteena on vahingoittaa kohdetta viestintäteknologian avulla. 
"Cyberbullying involves the use of information and communication technologies to support deliberate, repeated, and hostile behaviour by an individual or group, that is intended to harm others." (Belsey 2004)

Belseyn (2004) määritelmä korostaa uhrin vahingoittamisen tahallisuutta. Tutkijat ovat kuitenkin esittäneet arveluja siitä, onko kiusaaminen aina tietoista ja tahallista vahingoittamista, vai voisiko se joskus syntyä muiden sinänsä positiivisten vuorovaikutusilmiöiden (esim. ryhmän koheesion vahvistamisen) sivutuotteena (Pörhölä, Karhunen \& Rainivaara 2006). Kaikissa verkkokiusaamista käsittelevissä tutkimuksissa tutkimuskohdetta ei määritellä lainkaan. Esimerkiksi Lodge ja Frydenberg (2007) yksinkertaisesti toteavat, että verkkokiusaaminen on kiusaamista elektronisen viestinnän kautta. Useat tutkijat ovatkin tiedostaneet verkkokiusaamisen määrittelemisen ongelmat ja sen, että riittävän määrittelyn puuttuminen vaikeuttaa ilmiön tutkimista.

\section{Verkkokiusaamisen erityispiirteet}

Verkkokiusaamisen tutkimuksen ollessa vielä varsin nuorta kiusaamisen ominaispiirteet ovat herättäneet tutkijoiden mielenkiinnon. Willard (2007) on erottanut seitsemän verkkokiusaamisen muotoa:

1. Vihamielinen kommentointi (flaming): vihaisten, töykeiden tai alatyylisten viestien lähettäminen verkkoyhteisöön tai henkilölle suoraan esimerkiksi sähköpostilla tai tekstiviestillä

2. Häirintä (harassment): toistuva loukkaavien viestien lähettäminen henkilölle esimerkiksi sähköpostilla tai tekstiviestillä

3. Mustamaalaaminen (denigration): vahingollisten, perättömien tai julmien väitteiden kertominen henkilöstä jollekin toiselle tai vahingollisen materiaalin julkaiseminen internetissä

4. Toiseksi henkilöksi tekeytyminen (impersonation): harhauttaminen tai kohteen saattaminen huonoon valoon toiseksi ihmiseksi tekeytymällä.

5. Paljastaminen (outing and trickery): arkaluonteisen tai yksityisen informaation julkaiseminen, esimerkiksi henkilön yksityisten viestien tai kuvien julkaiseminen tai lähettäminen eteenpäin

6. Poissulkeminen (exclusion): henkilön poissulkeminen verkkoryhmästä tai -yhteisöstä

7. Verkkovainoaminen (cyberstalking): verkkohäirintä, joka sisältää uhkailua, tai häirintä koetaan muutoin uhkaavaksi.

(Willard 2007, 5-10) 
Verkkokiusaamisen uhri voi saada loukkaavia tai uhkaavia tekstiviestejä tai puheluita missä tahansa ja mihin tahansa aikaan. Tutkijat olettavatkin, että suurin osa lasten kokemasta kiusaamisesta tapahtuu itse asiassa koulupäivän ulkopuolella (Agatston, Kowalski \& Limber 2007; Mason 2008), mikä heikentää heidän turvallisuudentunnettaan (Kowalski \& Limber 2007; Slonje \& Smith 2008). Teini-ikäiset hallitsevat usein tietokoneen ja kännykän käytön paremmin kuin heidän vanhempansa, ja tietokone on sijoitettu nuoren yksityisalueelle tämän omaan huoneeseen (Patchin \& Hinduja 2006). Yksityisyys on nuorelle tärkeää, ja on havaittu, että vanhempien pyrkiessä kunnioittamaan nuoren yksityisyyttä he saattavat jäädä täysin tietämättömiksi verkossa piilevistä vaaroista (Li 2007b; 2008; Mishna, Saini \& Solomon 2009).

Internet on suhteellisen uusi ja laajalle ulottuva viestintäväline. Vaikka internetin keskustelufoorumeilla on omat valvojansa, ei kukaan ole tietoinen kaikesta materiaalista, jota on saatavilla muun muassa Myspacen, Facebookin, Youtuben ja tuhansien muiden sivustojen kautta. Lisäksi käyttäjien henkilökohtaiset viestit näkyvät vain lähettäjälle ja vastaanottajalle ja ovat siten valvonnan ulkopuolella. Kukaan ei myöskään tarkkaile tai sensuroi sähköpostien ja tekstiviestien mahdollista loukkaavaa sisältöä (Patchin \& Hinduja 2006).

Perinteisissä, kasvokkain tapahtuvissa kiusaamistilanteissa vierestä seuraajia on yleensä vain muutama. Verkkokiusaamisen yleisö voi olla määrältään rajaton (Kowalski \& Limber 2007). Internet mahdollistaa esimerkiksi juorujen levittämisen tai kuvien ja videotallenteiden lataamisen sekunneissa tuhansille ihmisille (Mason 2008; Slonje \& Smith 2008).

Verkko tarjoaa kiusaajille näkymättömyyden ja anonymiteetin (Slonje \& Smith 2008). Koska oppilaat voivat käyttää toisten henkilöiden puhelimia tai sähköpostitunnuksia tai pysyä nimettöminä, kiusaamiseen syyllistyneitä ei useinkaan saada vastuuseen (Kowalski \& Limber 2007). Virtuaalimaailmassa uhri ja kiusaaja eivät useinkaan näe toisiaan, mikä saattaa johtaa siihen, että kiusaaja ei myöskään tunnista aiheuttavansa kohteelleen vahinkoa. On oletettu, että ilman välitöntä palautetta ja uhrin emotionaalisten reaktioiden näkemistä empatian, katumuksen ja säälin kokeminen olisi epätodennäköisempää kuin kasvokkaistilanteissa (Kowalski \& Limber 2007; Li 2008; Slonje \& Smith 2008). Verrattuna perinteiseen kiusaamiseen verkkokiusaamisen erityispiirteisiin näyttäisi siis kuuluvan ainakin haitallisten viestien laaja leviäminen ja kontrolloimattomuus, loukkaavan viestinnän riippumattomuus ajasta ja paikasta, kiusaajan mahdollisuus pysytellä anonyymina sekä välittömän palautteen puuttumisen mahdollisesti synnyttämä tunteettomuus uhrin kärsimyksiä kohtaan.

\section{Verkkokiusaamisen tutkimuskohteet}

Verkkokiusaamisen tutkimus on keskittynyt pääasiassa ilmiön yleisyyden mittaamiseen, perinteisen kiusaamisen ja verkkokiusaamisen vertailuun sekä kiu- 
saamiseen käytettyjen viestimien tarkasteluun. Lisäksi on tutkittu kiusaamiskokemusten vaikutuksia uhrin hyvinvointiin sekä sitä, kenelle kiusaamisesta kerrotaan. Tutkimuksissa ei ole yleensä eroteltu kiusaajia ja kiusattuja, vaan heitä on tutkittu yhtenä joukkona. Henkilökohtaisia verkkokiusaamisen kokemuksia on kuitenkin tarkasteltu lähinnä kiusattujen näkökulmasta, ja tutkimuksissa on keskitytty pääasiassa kiusaamisen lyhyen aikavälin seurauksiin. Seuraavassa tarkastelemme erityisesti tutkimuksia, joissa on vertailtu perinteisen ja teknologiavälitteisen kiusaamisen osapuolten hyvinvointiongelmia.

Yksi yleisimmistä tarkastelun kohteista on ollut se, mitä elektronisia viestimiä kiusaamiseen käytetään ja millä välineellä on kielteisin vaikutus uhreihin. Esimerkiksi Slonjen ja Smithin (2008) 12-20-vuotiailta opiskelijoilta keräämä kyselyaineisto osoitti, että nuoret pitivät kuvien ja videoiden välityksellä tapahtuvaa kiusaamista haitallisimpana. Lisäksi ne vastaajat, jotka olivat itse joutuneet verkkokiusaamisen kohteeksi, pitivät kaikkia verkkokiusaamisen muotoja haitallisempina kuin perinteistä kiusaamista.

Verkkokiusaamisella oletetaankin olevan kiusaamisen uhreille vakavampia ja pitkäkestoisempia vaikutuksia kuin perinteisellä kiusaamisella. Monet perinteisen kiusaamisen uhrit kärsivät fyysisistä ja psykososiaalisista ongelmista kuten ahdistuneisuudesta, masentuneisuudesta, itsetuhoisista ajatuksista, syömishäiriöistä, erilaisista sairauksista ja vuorovaikutusongelmista sekä itsetunnon ja koulumenestyksen heikentymisestä (ks. esim. Pörhölä 2009). On myös tapauksia, joissa kiusaaminen on yhdistetty uhrin itsemurhaan (Campbell 2005; Hinduja \& Patchin 2007; Mason 2008).

Verkkokiusaamisen uhrit kokevat tutkijoiden mukaan enemmän ahdistuneisuutta ja epävarmuutta kuin perinteistä kiusaamista kokeneet, koska kiusaamisviestien mahdollinen yleisö on niin laaja ja tuntematon. Myös kiusaajan identiteetti jää usein uhrille epäselväksi. On oletettu, että vihollinen, jonka tunnemme, olisi vähemmän pelottava kuin vihollinen, jota emme tunne (Kowalski \& Limber 2007; Pure 2009; Slonje \& Smith 2008). Lisäksi uhri ei voi tietää, onko verkkokiusaamisen takana yksi henkilö vai isompi joukko ihmisiä ja kokee siitä syystä itsensä puolustuskyvyttömäksi ja kykenemättömäksi kontrolloimaan tilannetta (Pure 2009). Verkkokiusaamisen uhrien on todettu olevan myös huolissaan siitä, kuinka pitkään heitä vahingoittava video tai kuva on näkyvillä verkossa ja seuraako se heitä mahdollisesti jopa aikuisuuteen asti vaikeuttaen seurustelusuhteita tai työnsaantia (Li 2008; Pure 2009).

Tutkijat ovat olettaneet, että viestintäteknologia rohkaisisi kiusaajia anonymiteetin tarjotessa suojan sulkeutuneelle tai syrjäänvetäytyvälle henkilölle sellaisten aggressioiden toteuttamiseen, joita tämä ei koskaan ilmaisisi julkisesti (Campbell 2005; Li 2008; Patchin \& Hinduja 2006). Kuitenkin tarkastelemistamme verkkokiusaamisen empiirisistä tutkimusraporteista vain kahdessa oli perehdytty verkossa kiusaaviin nuoriin ja heidän sosiaaliseen käyttäytymiseensä. Ybarra ja Mitchell (2007) sekä Schultze-Krumbholz ja Scheithauer 
(2009) havaitsivat, että verkkokiusaamista harjoittavien nuorten empatiakyky oli heikko ja antisosiaalinen käyttäytyminen oli heille muita tyypillisempää. Verkkokiusaamista harjoittavat nuoret kärsivät monenlaisista mielenterveysongelmista ja psykososiaalisista ongelmista kuten runsaasta päihteiden käytöstä ja masentuneisuudesta ja olivat taipuvaisia aggressiiviseen käyttäytymiseen. Verkkokiusaamisella näyttäisi siis olevan merkittäviä kytkeymiä sekä kiusaavien että kiusattujen hyvinvointiin. Vaikka verkkokiusaamista pidetään jopa vahingollisempana kuin perinteistä kiusaamista, eroja näiden kiusaamismuotojen vaikutusten välillä on vaikea empiirisesti tutkia, koska samat yksilöt ovat useimmiten sekä perinteisen että verkossa tapahtuvan kiusaamisen osapuolina.

\section{Läheisten vuorovaikutussuhteiden merkitys kiusaamisprosesseissa}

Ystävyyssuhteet ja sosiaalinen hyväksyntä ovat erittäin tärkeitä lasten ja nuorten kognitiivisen kehityksen kannalta, ja niiden uskotaan vaikuttavan merkittävästi muun muassa identiteetin ja itsetunnon rakentumiseen (Campbell 2005; Patchin \& Hinduja 2006; Pure 2009; Samter 2003). Slonje ja Smith (2008) kysyivät verkkokiusaamisesta $12-20$-vuotiailta nuorilta ja havaitsivat, että useimmat kiusaamisen uhrit joko eivät kertoneet kiusaamisestaan kenellekään (50 \%) tai kääntyivät ystäviensä puoleen (35.7\%). Kukaan vastaajista ei ollut kertonut kiusaamisestaan opettajalle ja hyvin harvat olivat kertoneet vanhemmilleen. Cassidy kollegoineen (2009) puolestaan havaitsi, että kiusaamista kokeneet peruskouluikäiset raportoivat kiusaamisesta koulun henkilökunnalle todennäköisemmin kuin lukiossa olevat opiskelijat.

Erityisesti tytöt suosivat kiusaamisprosesseissa selviytymiskeinoja, jotka liittyvät sosiaalisen tuen hakemiseen ja sosiaaliseen toimintaan sekä jännitteiden vähentämiseen. Toisaalta tytöt syyttävät helpommin itseään kokemastaan kiusaamisesta. Pojat ovat ratkaisukeskeisempiä ja tekevät työtä ongelman selvittämiseksi. Pojat myös yrittävät tyttöjä useammin keskittyä positiivisiin asioihin ja hakevat tukea harrastuksista ja muusta fyysisestä toiminnasta. (Lodge \& Frydenberg 2007.)

On oletettu, että nuori, joka ei tiedä verkkokiusaajansa henkilöllisyyttä, saattaa pitää lähes jokaista vastaantulijaa potentiaalisena uhkana eikä tiedä, keihin ystävistään voi luottaa (Pure 2009). Toisaalta teknologia mahdollistaa myös ystävyyssuhteen rakentumisen verkossa ilman, että osapuolet tapaavat toisiaan lainkaan reaalimaailmassa. Verkossa kehittynyt ystävyyssuhde voi olla toisinaan jopa vahvempi ja syvempi kuin reaalimaailmassa rakennettu suhde. Tutkimukset ovat kuitenkin osoittaneet, että verkossa tavattu ystävä voi joskus paljastua eri ihmiseksi kuin tämä on kertonut olevansa (Kaare ym. 2007; Lenhart, Rainie \& Lewis 2001). Tällaisen verkkokiusaamisen muodon voisi olettaa olevan erityisen tuhoisa lapsen tai nuoren vertaisiaan kohtaan tuntemalle luottamukselle. 
Agatstonin ja kumppaneiden (2007) mukaan verkkokiusatut oppilaat eivät usko koulun henkilökunnan voivan auttaa heitä ja ovat myös haluttomia kertomaan kiusaamisesta vanhemmilleen, koska pelkäävät vanhempien tämän seurauksena rajoittavan heidän tietokoneen käyttöään kotona. Lasten internetin käytön seuraamista ja valvomista pidetään tärkeänä epäeettisen verkkokäyttäytymisen vähentämisessä, mutta sen uskotaan olevan tehokkaampaa silloin, kun lapsi kertoo vapaaehtoisesti tekemisistään vanhemmilleen. Pelkkä internetin käytön rajoittaminen tai liiallinen valvominen tuskin vähentää kiusaamista vaan saattaa pikemminkin haitata nuoren ystävyyssuhteita ja sitä kautta jopa lisätä kiusaamista. (Hart, Newell \& Frost Olsen 2003.)

Tulevaisuudessa olisi tarvetta tarkastella perusteellisemmin verkkokiusaamisen yhteyttä vanhemmuuteen, vanhemmuustyyleihin, vanhempien omiin sosiaalisiin taitoihin, mediakompetenssiin sekä heidän kykyynsä opettaa lapsilleen eettisesti hyväksyttävää nettikulttuuria ja verkossa tarvittavia sosiaalisia taitoja. Teknologian hallinnassa lapset ovat nykyään usein vanhempiaan osaavampia. Pieni lapsi oppii vuorovaikutustaitoja vanhempiensa kanssa yhdessä tekemällä (Hart, Newell \& Frost Olsen 2003), mutta nykyaikana yhdessä oleminen on vähentynyt lapsen istuessa yksin koneella. Mediakompetenssin opiskelu onkin olennaista, mutta edellyttää sitä, että sekä vanhempien että opettajien olisi tunnettava sosiaalista mediaa riittävän hyvin kyetäkseen ohjaamaan nuoria verkkoviestinnässä.

\section{Verkkokiusaamisen tutkimuksen haasteet}

Verkkokiusaamista pidetään monimutkaisena ilmiönä, koska virtuaalimaailman nähdään eroavan merkittävästi reaalimaailmasta (Spears ym. 2009). Teknologia kiinnittyy kuitenkin yhä vahvemmin ihmisten väliseen kommunikointiin, eikä verkkokiusaamista tulisi nähdä reaalimaailmasta erillisenä ongelmana. Perinteinen kiusaaminen ja verkkokiusaaminen tapahtuvat usein limittäin tai niin, että toisesta seuraa toista. Yhtäältä tiedetään, että kasvokkain tapahtuva kiusaaminen usein jatkuu verkossa, ja toisaalta esimerkiksi henkilöstä lähetetyt loukkaavat viestit tai videot saattavat aiheuttaa kaveriporukan ulkopuolelle jäämisen reaalimaailmassa.

Tulevaisuudessa virtuaalimaailman erottaminen reaalimaailmasta käykin yhä vaikeammaksi ja jopa merkityksettömäksi. Verkkokiusaamisen tutkimuksissa ei ole vielä ehditty ottaa huomioon esimerkiksi älypuhelimia tai niin kutsuttuja taulutietokoneita, jotka mahdollistavat entistä paremmin sen, että vuorovaikutus voi tapahtua yhtä aikaa verkossa ja kasvokkain. Kiusaamisen välineet ja keinot nivoutuvat tulevaisuudessa vielä enemmän yhteen, eikä esimerkiksi tekstiviestiä, sähköpostia tai vaikkapa Facebookin chat-viestiä voi enää erottaa selvästi toisistaan. Tämä tuottaa haasteita niin verkkokiusaamisen määrittelemiselle kuin sen tutkimiseen käytettäville menetelmillekin. 
Verkkokiusaamisen tutkimus on muutamaa poikkeusta lukuunottamatta ollut kvantitatiivista. Tutkimusmenetelminä on käytetty verkossa täytettäviä kyselylomakkeita ja puhelinhaastattelua. Tutkittavat ovat useimmiten valikoituneet itse. Verkkokiusaamisen tutkimiseen on usein käytetty mittareita, joita ei ole alunperin suunniteltu mittaamaan verkkokiusaamista tai kiusaamista ylipäätään. Mittareiden kehittelylle olisikin selvästi tarvetta. Toisaalta laadullisen tutkimuksen avulla olisi mahdollista päästä lähemmäksi lasten ja nuorten maailmaa ja verkkokiusaamisen erityispiirteitä.

Lapset ja nuoret ovat tutkimuskohteina haastavia ja asettuvat jo ikänsä puolesta tutkijan kanssa erilaiseen asemaan. Lisäksi kiusaaminen on monelle arka ja vaikea aihe, ja siitä kertominen voi olla hankalaa. Ryhmähaastattelut ja -keskustelut voisivat tuottaa tärkeää tietoa verkkokiusaamisen luonteesta lasten ja nuorten jäsennellessä kokemuksiaan ja havaintojaan ikäistensä seurassa.

Toistaiseksi tutkijat eivät ole hyödyntäneet verkkokiusaamisen tutkimuksessa itse verkkoa kovinkaan laajasti. Verkkokiusaaminen tapahtuu usein tekstin, kuvien tai videon avulla, ja nämä konkreettiset todisteet jäävät yleensä talteen. Verkkokiusaamisen tutkimuksessa olisi siis mahdollista käyttää myös valmiita dokumentteja kuten kiusaajan lähettämiä tekstiviestejä tai Facebookiin perustettua vihasivua. Verkkoon tallentuu kiusaajan lähettämän tekstin tai kuvan lisäksi myös viestien määrä ja ajankohta. Verkkoon ladattujen videoiden ollessa tutkimuksen kohteena myös niiden katsomiskerrat ja niihin liitetyt kommentit sisältävät arvokasta tutkimustietoa kiusaamisen rakenteesta ja etenemisestä. Tällaisia valmiita dokumentteja voitaisiin käyttää kiusaamisviestinnän sisällölliseen analyysiin. Uusilla, monipuolisilla menetelmillä voitaisiin syventää merkittävästi teknologiavälitteisen kiusaamisen tutkimusta.

\section{Kirjallisuus}

Agatston, P. W., Kowalski, R. \& Limber, S. 2007. Students' perspectives on cyber bullying. Journal of Adolescent Health 41, 59-60.

Belsey, B. 2004. Cyberbullying.org. Viitattu 28.4.2011. http://www. cyberbullying.org/pdf/Cyberbullying_Information.pdf

Beran, T. \& Li, Q. 2005. Cyber-harassment: A study of a new method for an old behavior. Journal of Educational Computing Research 32 (3), 265-277.

Beran, T. \& Li, Q. 2007. The relationship between cyberbullying and school bullying. Journal of Student Wellbeing 1 (2), 15-33.

Buckingham, D. 2004. The electronic generation? Children and new media. In L. A. Lievrouw \& S. Livingstone (eds.) The handbook of new media. London: Sage, 77-89.

Campbell, M. A. 2005. Cyber bullying: An old problem in a new guise? Australian Journal of Guidance \& Counselling 15 (1), 68-76. 
Cassidy, W., Jackson, M. \& Brown, K. N. 2009. Sticks and stones can break my bones, but how can pixels hurt me? Students' experiences with cyberbullying. School Psychology International 30 (4), 383-402.

Hart, C. H., Newell, L. D. \& Frost Olsen, S. 2003. Parenting skills and socialcommunicative competence in childhood. In J. O. Greene \& B. R. Burleson (eds.) Handbook of communication and social interaction skills. Mahwah, NJ: Erlbaum, 753-797.

Hinduja, S. \& Patchin, J. W. 2007. Offline consequences of online victimization. Journal of School Violence 6 (3), 89-112.

Juvonen, J. \& Gross, E. F. 2008. Extending the school grounds? Bullying experiences in cyberspace. Journal of School Health 78, 496-505.

Kaare, B. H., Brandtzæg, P. B., Heim, J. \& Endestad, T. 2007. In the borderland between family orientation and peer culture: The use of communication technologies among Norwegian tweens. New Media \& Society 9 (4), 603-624.

Katzer, C., Fetchenhauer, D. \& Belschak, F. 2009. Cyberbullying: Who are the victims? A comparison of victimization in internet chatrooms and victimization in school. Journal of Media Psychology 21 (1), 25-36.

Kowalski, R. M. \& Limber, S. P. 2007. Electronic bullying among middle school students. Journal of Adolescent Health 41, 22-30.

Lenhart, A., Rainie, L. \& Lewis, O. 2001. Teenage life online. Washington: Pew Internet \& American Life Project.

Li, Q. 2007a. Bullying in the new playground: Research into cyberbullying and cyber victimisation. Australasian Journal of Educational Technology 23 (4), 435-454.

Li, Q. 2007b. New bottle but old wine: A research of cyberbullying in schools. Computers in Human Behavior 23, 1777-1791.

Li, Q. 2008. A cross-cultural comparison of adolescents' experience related to cyberbullying. Educational Research 50 (3), 223-234.

Lodge, J. \& Frydenberg, E. 2007. Cyber-bullying in Australian schools: Profiles of adolescent coping and insights for school practitioners. The Australian Educational and Developmental Psychologist 24 (1) 45-58.

Mason, K. L. 2008. Cyberbullying: A preliminary assessment for school personnel. Psychology in the Schools 45 (4), 323-348.

Mishna, F., Saini, M. \& Solomon, S. 2009. Ongoing and online: Children and youth's perceptions of cyber bullying. Children and Youth Services Review $31,1222-1228$.

Olweus, D. 1993. Bullying at school: What do we know and what can we do. Oxford, UK: Blackwell.

Ortega, R., Elipe, P., Mora-Merchán, J. A., Calmaestra, J. \& Vega, E. 2009. The emotional impact on victims of traditional bullying and cyberbullying: A study of Spanish adolescents. Journal of Psychology 217 (4), 197-204.

Patchin, J. W. \& Hinduja, S. 2006. Bullies move beyond the schoolyard: A preliminary look at cyberbullying. Youth Violence and Juvenile Justice 4 (2), 148- 169. 
Pure, R. A. 2009. Uncertainty and psychological consequences due to cyberbullying. In T. A. Kinney \& M. Pörhölä (eds.) Anti and pro-social communication: Theories, methods, and applications. Language as Social Action, Vol. 6. New York: Lang, 41-48.

Pörhölä, M. 2009. Psychosocial well-being of victimized students. In T. A. Kinney \& M. Pörhölä (eds.) Anti and pro-social communication: Theories, methods, and applications. Language as Social Action Vol. 6. New York: Lang, 83-93.

Pörhölä, M., Karhunen, S. \& Rainivaara, S. 2006. Bullying at school and in the workplace: A challenge for communication research. In C. S. Beck (ed.) Communication Yearbook 30. Mahwah, NJ: Erlbaum, 249-301.

Samter, W. 2006. Friendship interaction skills across the life-span. In J. O. Greene \& B. R. Burleson (eds.) Handbook of communication and social interaction skills. Mahwah, NJ: Erlbaum, 637-684.

Schultze-Krumbholz, A. \& Scheithauer, H. 2009. Social-behavioral correlates of cyberbullying in a German student sample. Journal of Psychology 217 (4), 224-226.

Ševcíková, A. \& Šmahel, D. 2009. Online harassment and cyberbullying in the Czech Republic, comparison across age groups. Journal of Psychology 217 (4), 227-229.

Slonje, R. \& Smith, P. K. 2008. Cyberbullying: Another main type of bullying? Scandinavian Journal of Psychology 49, 147-154.

Spears, B., Slee, P., Owens, L. \& Johnson, B. 2009. Behind the scenes and screens: Insights into the human dimension of covert and cyberbullying. Journal of Psychology 217 (4), 189-196.

Willard, N. E. 2007. Cyberbullying and cyberthreats: Responding to the challenge of online social aggression, threats and distress. Champaign, IL: Research Press.

Ybarra, M. L. \& Mitchell, K. J. 2004. Youth engaging in online harassment: Associations with caregiver-child relationships, internet use, and personal characteristics. Journal of Adolescence 27, 319-336.

Ybarra, M. L. \& Mitchell, K. J. 2007. Prevalence and frequency of internet harassment instigation, implications for adolescent health. Journal of Adolescent Health 41, 189-195. 